\title{
Doação do Acervo Milton Santos
}

Em agosto de 2008, foi incorporado ao Acervo do Instituto de Estudos Brasileiros da USP, mediante doação da família, o Acervo do intelectual e geógrafo baiano Milton Santos, composto de todos os seus livros e arquivo de pesquisa. A aquisição reforça ainda mais o patrimônio do IEB proveniente de fundos documentais e material bibliográfico de coleções de intelectuais de diversas áreas das Ciências Humanas, que já integram o Acervo da instituição, tais como os de Yan de Almeida Prado, Alberto Lamego, José Honório Rodrigues, Caio Prado Jr. e Pierre Monbeig, dentre outros.

Para além do processamento técnico, um dos trabalhos acadêmicos a serem executados para a recepção do Acervo Milton Santos será a organização pelo IEB, em conjunto com o Departamento de Geografia da Faculdade de Filosofia, Letras e Ciências Humanas da USP e com a Faculdade de Arquitetura e Urbanismo da USP, de um seminário, a ser realizado em junho de 2009 , sobre a obra do titular. O evento contará com a presença de intelectuais de diversas instituições nacionais e internacionais, propondo-se a problematizar, de forma interdisciplinar, as categorias elaboradas e desenvolvidas pelo geógrafo para três níveis de análise: a Cidade, o Brasil e o Mundo Hoje, nos seus desafios e perspectivas.

A trajetória do intelectual e suas contribuições serão abordadas a partir dos seguintes temas: 1) O território usado e a perversidade da crise; 2) Formações socioespaciais do Terceiro Mundo: qual é hoje o desafio?; 3) O Meio Técnico Científico Informacional: a cara geográfica da globalização; 4) O espaço dividido nas cidades do século XXI e 5) A força do lugar: na encruzilhada das verticalidades e horizontalidades. 